\title{
プラズマジェツトを用いた減圧下での 高融点材料処理
}

\author{
正員 福 政 修 (山口大) \\ 正員崎 山 智司 (山口大)
}

\section{Application of a Plasma Jet Reactor to Low Pressure Processing of Refractory Materials \\ Osamu Fukumasa, Member, Satoshi Sakiyama, Member (Yamaguchi University)}

In order to demonstrate the application feasibility of the reactor composed of a forced constricted type DC plasma jet generator and a feed ring to low pressure plasma processing, we have studied the production of ultrafine particles of refractory materials $\left(\mathrm{Al}_{2} \mathrm{O}_{3}, \mathrm{ZrC}, \mathrm{TiC}\right)$ and the interaction between the plasma flow and the injected particles.

According to the experimental results, many ultrafine particles whose diameters are less than $0.1 \mu \mathrm{m}$ are prepared not only in atmospheric pressure but also in low pressure, although the number density of the prepared ultrafine particles, $\mathrm{N}$, in low pressure is usually less than that in atmospheric pressure. It is also found that we can control the process of particle heating by changing the feed ring length, and that $\mathrm{N}$ in low pressure becomes equal to or greater than $\mathrm{N}$ in atmospheric pressure with increasing the feed ring length.

キーワード：熱プラズマプロセス, プラズマジェット, フィードリング, 高融点材料, 超微粒子

\section{1. まえがき}

プラズマ中の電子, イオンやラジカルのもつ豊かな 反忘性を精密に制御して (1)，材料生成や表面処理など へ応用するプラズマプロセスは近年重要な先端技術の 一つとなってきた。このようなプラズマプロセスに利 用されるプラズマは, 主に低圧力下で用いられる低温 プラズマと大気圧下で用いられる熱プラズマに大別さ れる。それぞれのプラズマの特徵に対応して，低温プ ラズマは大面積にわたって均一にプロセスを行いうる が反応速度が低いという弱点があり，熱プラズマは高 い反応率で材料処理が可能であるという利点をもつが 大容量化は簡単ではない。

プラズマジェットはアーク放電をガス流と器壁で強 制集束することによって容易に得られる熱プラズマで 高温化学反応(2), 高融点材料処理 ${ }^{(3)}$, 高速成膜(4)など への応用が注目されている。著者らも,プラズマジェ
ットを用いた熱プラズマプロセスに関心をもち高融点 材料の超微粒子生成やスプレイコーティング(5)(6)，ダ イヤモンド合成(7)検討している。その目的は減圧下 でプラズマジェットを用いてプロセスを行うことによ り，熱プラズマとしての利点である高い反応速度を維 持したまま，低温プラズマの特長であるプロセスの大 容量化抒よび均一化を図ることにある。なお，隇圧下 でのプロセスは不純物の混入も少なくプロセスの高品 質化にもつながる。この目標を達成するには，まず， (i ) 広い圧力範囲にわたって所用のプラズマを安定に 供給するプラズマ源と処理物質を高温のプラズマ流内 に注入して効果的なプロセスを行う反応器の開発, 更 に，(ii)プロセス制御の立場からプラズマ流の粒子密 度, 温度, 速度などの精密測定と同時に, プラズマ流 とプロセス材料（特に粉末材料）間の熱移動などの相 互作用の解明が重要な課題となる。

著者らは, 課題 ( i ) に関して, 強制伸長型プラズマ 
ジェット発生器(8)の前面に材料送給用のフィードリン グ（以下 FR と略記）を接続したプロセシング装置を 既に提案し(9)検討を進めてきた。その基礎特性を調べ ることにより，本装置は減圧下・粉末材料送給に対し て安定でり，かつ高出力が得られることが判明 $乙^{(9)(10)}$ ，現在はこの装置を用いて具体的なプロセスの 検討を進めている(6)(7)。

そこで本研究では，課題（ii）に関連して，熱プラズ マプロセスでよく扱われる, 高融点粉末材料を対象に してプラズマ流との相互作用について検討した。すな わち，FRは材料粒子とプラズマ流の有効な混合領域 として作用している点に注目して，FR 長が減圧下て の粒子加熱，ならびに微粒子生成に与える影響につい て実験的に調べた。

更に, このプロセシング装置で容器圧力ゃ粒径など が粒子の加熱過程に与える影響をモデル計算によって 調べ，材料粒子とプラズマ流との相互作用について基 礎的な検討も行った。そして,このプロセシング装置 の減圧下での高融点材料処理への応用可能性について 検討した。

\section{2. 実験装置および実験方法}

〈2・1〉プロセシング装置実験装置は図 1 に示 すように強制伸長型プラズマジェット発生器のノズル 出口に FR を設け, 更にその下流側に雾囲気圧力を制 御するための圧力容器を接続し構成している(9)(10)。

強制伸長型プラズマジェット発生器は, 陰極と陽極 間にノズル状の絶緑集束部を有している点が通常型の プラズマジェット発生器とは異なっている。この絶縁 集束部により陽極点がノズル先端に固定されアーク長 は一定に保持される。更に，アークはノズル壁捛よび
ガス流によってノスル軸線上に集束されるため, 安定 で高い熱出力のプラズマジェットを得ることができ る。この絶縁収束ノズルの内径は $5 \mathrm{~mm} \phi$, 軸長は $6 \mathrm{~mm}$ である。また，ノズル型陽極㹥内径 $5 \mathrm{~mm} \phi の$ 銅製で，棒陰極には直径 $5 \mathrm{~mm} \phi の 2 \% \mathrm{Th}-\mathrm{W}$ を用い た。

プラズマ流への処理材料の供給方法にはアークに直 接供給する方法とプラスマジェットに供給する方法の 2 種類がある。しかし, 前者は加熱効率が高い反面, 不純物混入によるアークの不安定性や電極の腐食など の問題があり，後者は陽極ノズル噴出後のプラズマジ エットは拡散・膨張しているため温度が低く粒子の加 熱効率が悪いという久点がある。そこで，本装置では 陽極ノズルの下流に陽極と同じ内径をもつ FR を陽極 と電気的に絶緑し設け，この FR 内のプラズマ流へ処 理材料を供給する方法が用いられている。この方法 は，プラズマ流をFR内に閉込め，搪散・膨張に伴う 温度低下を防ぎ，処理材料の効果的な加熱を可能とす るだけでなく、アークや電極への悪影響もほとんど生 じないという利点をもつ。今回用いた FR(銅製，内 径 $5 \mathrm{~mm} \phi)$ は軸長が $9.5,15.5,21.5 \mathrm{~mm}$ の 3 種類 (以下それぞれ FR 1，FR 2，FR 3 とする) である。 その構造を図 2 に示す。

なおいずれのFRにおいても材料送給口（1.4 $\mathrm{mm} \phi)$ FR 入口上り $3.5 \mathrm{~mm}$ 下流の位置に軸線に 対し垂直に 2 個設けている。そのため材料粒子が FR 内で加熱を受ける距離 $\left(l_{m}\right)$ は FR 1, FR 2, FR 3 の 順に 6, 12, $18 \mathrm{~mm}$ となる。なお，本論文では FR 内 の比較的高温のプラズマ流を単にプラズマ流, FR 嘈 出後のプラズマ噴流をプラズマジェットと呼ぶ使いわ けを行っている。

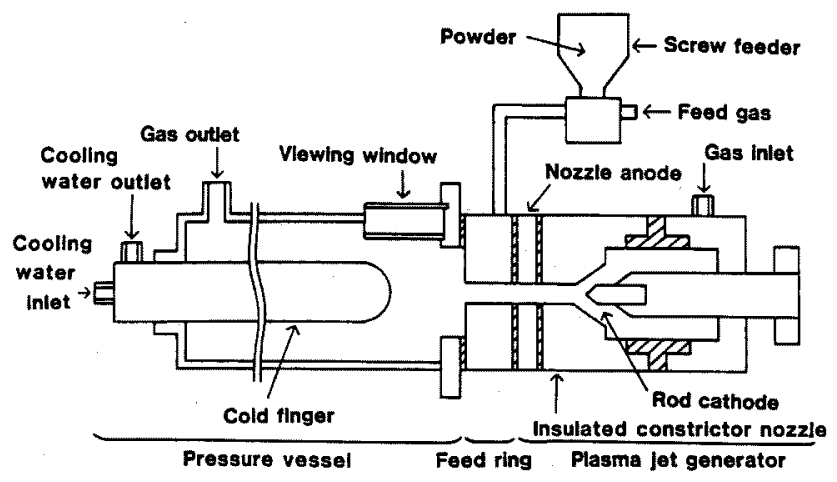

図 1 プロセシング装置

Fig. 1. Schematic view of a plasma processing device mainly composed of a plasma jet. 


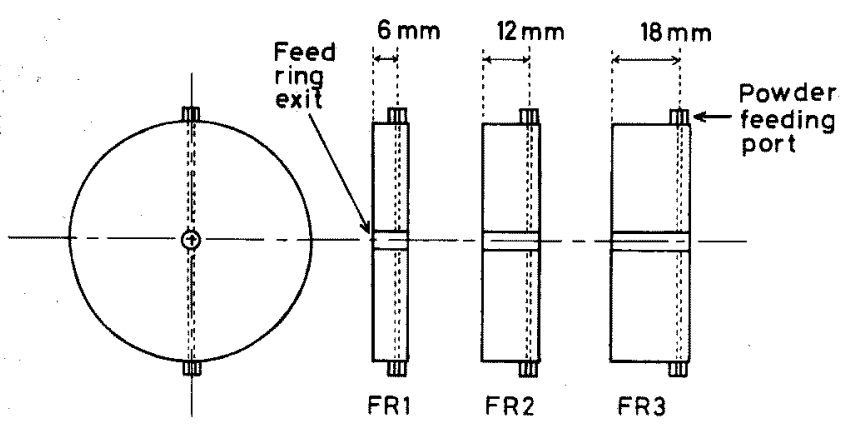

図 2 フィードリング

Fig. 2. Three feed rings used in the experiment.

圧力容器 (内径 $70 \mathrm{~mm} \phi$, 長さ $480 \mathrm{~mm}$ ) は FR の下流側に接続され, 容器内の圧力は真空ポンプ (100 l/min) 2 台とニードルバルブによって調節され る。またここの容器には観測空 $(35 \mathrm{~mm} \times 120 \mathrm{~mm})$ を設けておる゙プロセス進行中のジェットの観測が可能 である。

〈2・2〉実験方法および実験条件＼cjkstart処理材料には $\mathrm{Al}_{2} \mathrm{O}_{3}$ (平均粒径 $20 \mu \mathrm{m}$, 粒径分布 $10 \sim 44 \mu \mathrm{m}$, 融点 $\left.2,040^{\circ} \mathrm{C}\right), \mathrm{ZrC}\left(22 \mu \mathrm{m}, 10 \sim 53 \mu \mathrm{m}, 3,570^{\circ} \mathrm{C}\right), \mathrm{TiC}$ $\left(21 \mu \mathrm{m}, 10 \sim 44 \mu \mathrm{m}, 3,140^{\circ} \mathrm{C}\right)$ の粉末を使用し, こ れをフィードガスに混入し FR 内のプラズマ流に送給 した。また，プラズマジェット中で生成された微粒子

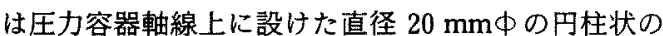
銅製コールドフィンガ（先端部は半球状）を用いて捕 集した。具体的にはコールドフィンガの側面にガラス 板（幅 $4 \mathrm{~mm}$ ，長さ $115 \mathrm{~mm}$ ）を取付け，その表面に 付着した生成粒子を回収することによって行った。材 料送給時間は 1 回あたり 2 分で一定とし,FR出口か らコールドフィンガ先端までの軸線上の距離 $(L)$ は 20〜200 mm の範囲で変化させた。なお, 回収した生 成粒子は走查型電子顕微鏡（SEM）を用いて観察し た。

FRより噴出したプラズマジェットの温度分布は， ノズル出口付近の $4,000 \mathrm{~K}$ 以上の高温部は分光学的方

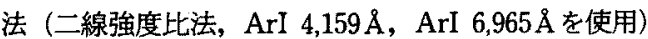
を用いて求め, $3,000 \mathrm{~K}$ 以下の低温部は $\mathrm{W} \cdot \operatorname{Re}(5 \%)$ $\mathrm{W} \cdot \operatorname{Re}(26 \%)$ 熱電対により測定した。また，流速は ピト一管（外径 $6 \mathrm{~mm} \phi$, 内径 $1 \mathrm{~mm} \phi)$ を用いて測 定した。

実験条件は容器圧力 $(P) 760,100$ Torr, 作動ガ

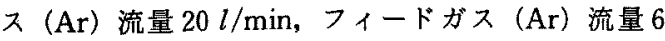
$l / \mathrm{min}$ ，材料粒子送給量 $0.5 \mathrm{~g} / \mathrm{min}$ である。なお，ジ エット熱出力は $3.0 \mathrm{~kW}$ 一定とした。

\section{3. 実験結果および検討}

\section{〈3・1〉プロセシング装置の隇圧下での諸特性}

（1）プロセシング装置の基礎特性 強制伸長型 プラズマジェット発生器のアーク電圧対アーク電流の 関係は図 3 に示すように，大気圧下だけでなく低圧力 下においても上昇特性を示す(6)。通常型の発生器では この電流範囲では垂下特性を示している。このため強 制伸長型プラズマジェット発生器を用いると電流の增 加に伴い効果的に入力の增大を図ることが可能とな る。また，異なる長さの FR を装着した場合のアーク 電圧の差は $5 \%$ 以内であり，FR 長の違いはアーク特 性にほとんど影響を与えない。

このほかに著者らは, 容器圧力の変化, 粉末材料や 反応性ガスの送給がアーク特性に与える影響は軽微て あることも確認している(6)(7)(10)。すなわち，本装置 は, 処理材料の注入や容器圧力の変化などに対しても 発生器の基礎的な特性はほとんど影響を受けず，常に 安定で高温のプラズマジェットの発生が可能である。

（2）プラズマ流の温度場抒よび速度場 図 4, 図 5 は FR 噴出後のプラズマジェットの温度抢よび速 度の二次元分布を示す。温度は〈2・2〉節で示したよう に熱電対と分光学的方法を用い, 流速はピト一管を用 いて測定した。

温度は，中心軸上で最大值をとり外周部に向かうに 従って減少する分布をとる。FR出口から $4 \mathrm{~mm}$ 下流 の中心軸上においても温度は約 $5,500 \mathrm{~K}$ 以上を維持し ており，また，FR内の温度䋇後述の図 10 に示すよ うに FR 噴出後の温度より高温である。つまり，いず れの領域においてもプラズマ流の温度は高融点材料の 融点に比べ十分高い值を有している。また，圧力を減 じた場合，等温線は径方向および軸方向に広がり，高 温領域は拡大するので，プロセスの大面積化が期待で 


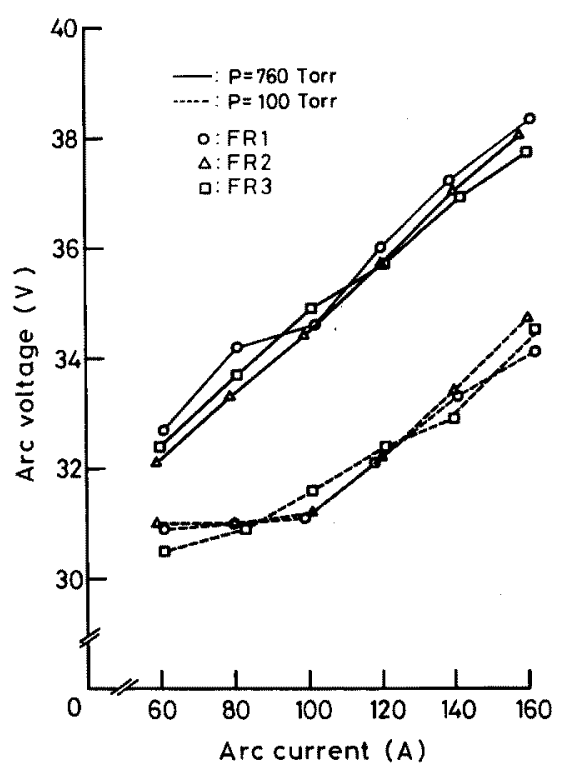

図 3 アーク電圧対アーク電流の関係

Fig. 3. Arc voltage vs. arc current for three feed rings.

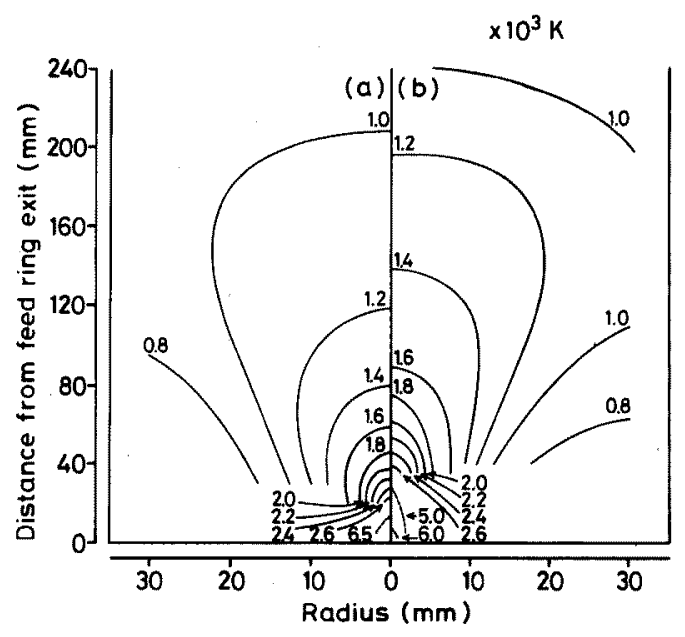

$\begin{array}{ll}\text { (a) } 760 \text { Torr } & \text { (b) } 100 \text { Tor }\end{array}$

図 4 実験により測定したFR 噴出後の プラズマジェットの温度分布

Fig. 4. Temperature fields of the plasma jet measured in experiment for different two pressures.

きる。

一方，速度分布も低圧力下では高速度の領域が拡大 する。例えば中心軸上で FR 出口から $50 \mathrm{~mm}$ 下流で

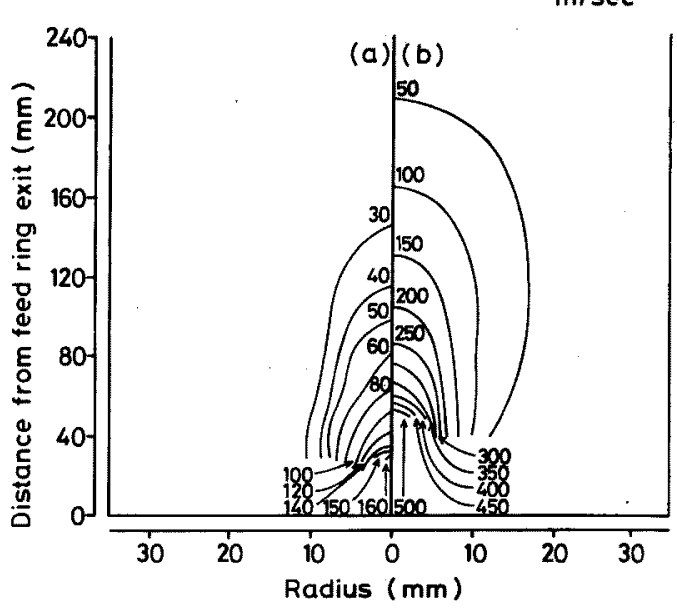

$\begin{array}{ll}\text { (a) } 760 \text { Torr } & \text { (b) } 100 \text { Torr }\end{array}$

図 5 実験により測定した FR 噴出後の プラズマジェットの速度分布

Fig. 5. Velocity fields of the plasma jet measured in experiment for different two pressures.

速度は約 $100 \mathrm{~m} / \mathrm{s}$ であるが，低圧力下では同位置の 速度は的 $530 \mathrm{~m} / \mathrm{s}$ と高速になる。すなわち，圧力を 隇じることにより高温高速の領域が拡大することにな 万。

〈3・2〉 微粒子生成に及ぼす圧力の影䇾 プラズ マジェットを用いるプロセスでは粉末材料の加熱過程 の制御が重要である。ここでは材料粒子とプラズマ流 の相互作用を微粒子生成を通して実験的に検討する。 特に容器圧力および FR 長が微粒子生成に及ぼす影響 について，処理材料として $\mathrm{Al}_{2} \mathrm{O}_{3}$ を用いた場合を例に 検討する。

（1）FR 長が微粒子生成に及侣す影響 プラズ マ流に対し材料送給を行った場合に回収された生成粒 子の SEM 写真を, 処理前の粒子と比較して図 6 に示 す。どの FRを使用しても同様の観剆結果が得られる ため,ここではFR 1 (加熱を受ける距嚄 $l_{m}=6 \mathrm{~mm}$ ) で得られた結果の一例を示す。処理前の材料粒子は (a)図に示すように不定形な多角形状をしている。こ れに対し回収された生成粒子は（c），(e)図に見られ るように, 大部分が $5 \mu \mathrm{m}$ 以下に微粒子化されてい る。またその形状は，P=760 Torr ではほとんどが球 状を呈するが, 100 Torr では不規則な形状の粒子が 含まれる。これは隇圧下におけるプラズマジェットが 著しく高速度のため加熱溶融した材料粒子が高速でコ ールドフィンガや捕集板に衝突するためと考えられ 


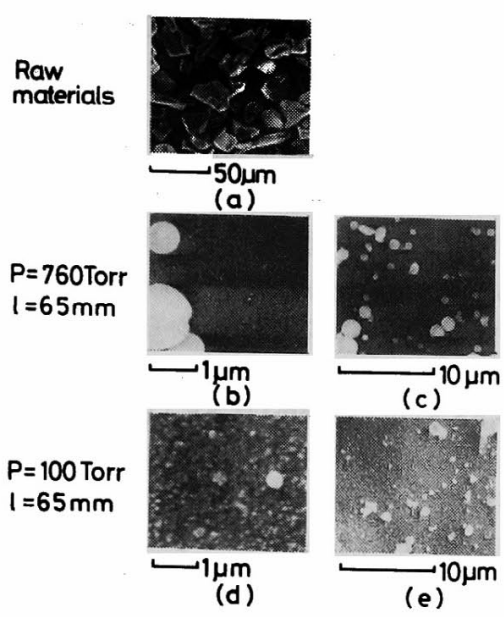

lはFR 出口から回収位置までの距離

図 $6 \mathrm{Al}_{2} \mathrm{O}_{3}$ 粒子の SEM 写真

Fig. 6. SEM photographs of raw powder materials and fine particles prepared.

る。しかし，いずれの圧力においても，更に高倍率で 観察すると (b)，（d）図に見られるような超微粒子と 呼ばれる $0.1 \mu \mathrm{m}$ 以下の微粒子が密集している状態が 確認される。これらのSEM写真より, 単位面積 $\left(0.1 \times 0.1 \mathrm{~mm}^{2}\right)$ あたりの粒子数（粒子数密度）を求 め, その粒径分布を調べると, 回収された粒子数の約 $99 \%$ が粒径 $0.1 \mu \mathrm{m}$ 以下であった。処理前の材料粒子 の粒径分布は, $10 \sim 44 \mu \mathrm{m} て ゙ 12 \sim 20 \mu \mathrm{m}$ の粒子が 約 75\%を占めていること,および $\mathrm{Al}_{2} \mathrm{O}_{3}$ の沸点が $3,773 \mathrm{~K}$ の高温であることを考慮すると, 注入された 粒子はプラズマ中の高温領域までうまく侵入し, 溶 融・蒸発が行われているものと考えられる。注入され た材料粒子に対する微粒子化された粒子の割合につい ては現在検討中であるが，減圧下においても本装置を 用いて高融点材料の微粒子化が十分可能であることが わかる。

次に, FR 長の変化が超微粒子の生成に及ほす影響 を図 7 に示す。この図は FR 出口から回収位置までの 距離 $(l)$ に対して, 捕集された生成粒子のうちの超微 粒子の数密度を示したものである。ここでは粒子の数 密度の $l$ 依存性を問題としているが, 実験では FR 出 ロからコールドフィンガ先端までの距離 $L$ をいろい ろ変化させて粒子を回収した。図 7 にはそのデータを プロットしている。そのため同一の $l$ の位置に観測值 が 2 個存在する場合がある。

FR $1\left(l_{m}=6 \mathrm{~mm}\right)$ を使用した場合には $l$ の増加に伴 い粒子数密度が減少する傾向を示すが, FR $2\left(l_{m}=\right.$

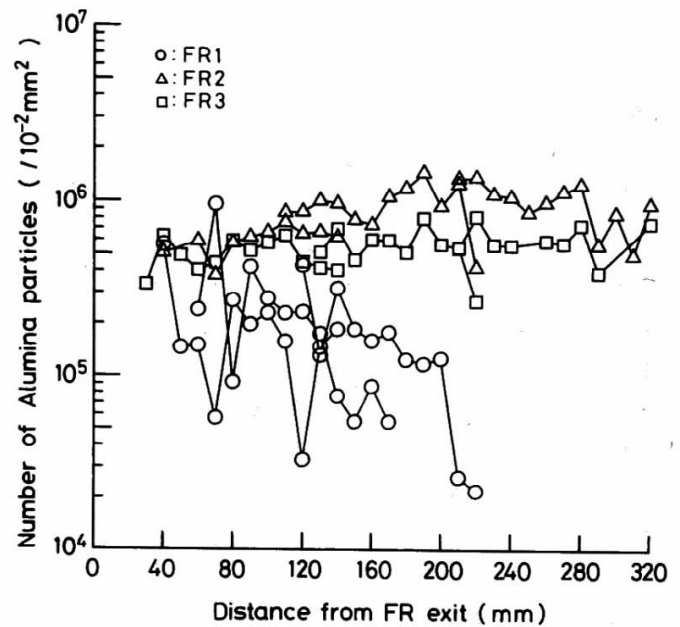

(a) 760 Torr

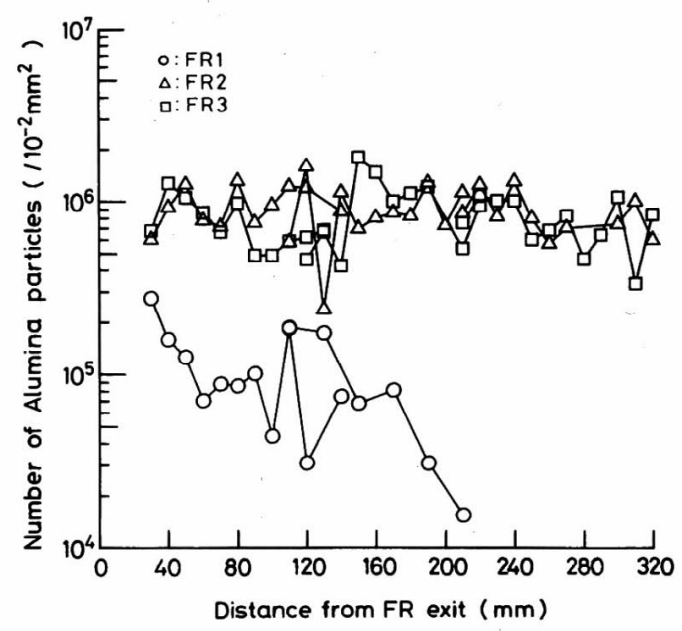

(b) 100 Torr

図 $7 \mathrm{Al}_{2} \mathrm{O}_{3}$ 超微粒子（半径 $\leq 0.1 \mu \mathrm{m}$ ) の 数密度の軸方向分布

Fig. 7. Number density of $\mathrm{Al}_{2} \mathrm{O}_{3}$ ultrafine particles (diameter $\leq 0.1 \mu \mathrm{m}$ ) as a function of the distance from the FR exit.

$12 \mathrm{~mm}), \mathrm{FR} 3\left(l_{\mathrm{m}}=18 \mathrm{~mm}\right)$ では $l$ に無関係にほほ一 定值となっている。また, FR $1\left(l_{m}=6 \mathrm{~mm}\right)$ と比較し て FR 長の長いFR $2\left(l_{m}=12 \mathrm{~mm}\right)$, FR $3\left(l_{m}=18\right.$ $\mathrm{mm})$ のほうが回収される超微粒子の粒子数密度が高 い。この FR 長を延長すると回収される粒子数が増加 する傾向は減圧下ほど顕著である。一例として $l=80$ $\mathrm{mm}$ における粒子数密度を挙げる。まず, FR1 $\left(l_{m}=\right.$ $6 \mathrm{~mm})$ を装着した場合, 圧力を 760 Torr から 100 Torr に減じると回収される粒子数は約 $1 / 2$ に減少す 
る。しかし，FR3 $\left(l_{m}=18 \mathrm{~mm}\right)$ を装着すると, 760 Torr では FR $1\left(l_{m}=6 \mathrm{~mm}\right)$ の約 2 倍の約 $6 \times 10^{5}$ 個, 100 Torr では約 10 倍の約 $9 \times 10^{5}$ 個に增加する。すな わち，一般論として予測されるごとく圧力を減じると 回収される粒子数は減少する。しかし，FR 長を延長 すれば大気圧下と同程度の生成粒子を回収することが できることがわかる。このように，回収された超微粒 子の粒子数密度が増加するのは FR 長を延ばすことに よって生成量そのものが増加したためと考えられる。 以上の実験結果と後述の計算結果を考え合せると， 容器圧力を減じるとプラズマ流から材料粒子への熱伝 達量が低下し, 粒子は加熱されにくくなるが, FR 長 を延長することで粒子加熱が改善されることがわか る。

また著者らは $\mathrm{Al}_{2} \mathrm{O}_{3}$ 粒子よりも更に高融点を有する

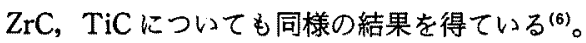

(2) プラズマジェットの温度と FR 長の関係

ここでは(1)項で述べた，FRを延ばすことによる 回収粒子数密度の增加とプラズマジェットの温度分布 の関係について考元る。

図 8 は FR 出口から $4 \mathrm{~mm}$ 下流の位置におけるプラ ズマジェットの温度の径方向分布を FR $1\left(l_{m}=6 \mathrm{~mm}\right)$ とFR 3 $\left(l_{m}=18 \mathrm{~mm}\right)$ について示したものである。図 よりプラズマジェット軸線上の温度は $P=760$ Torr

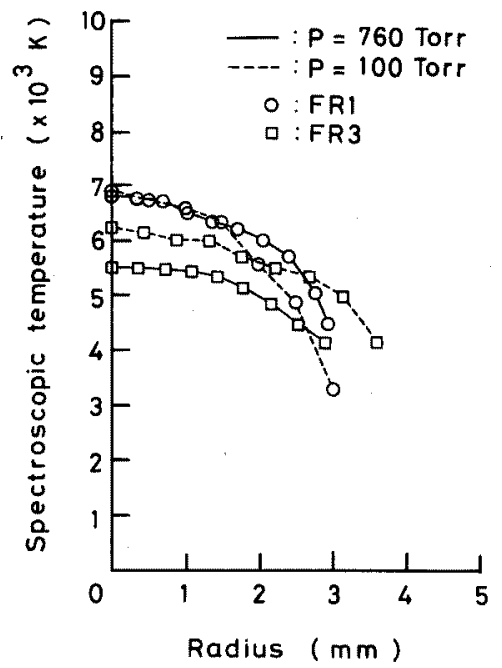

図 8 プラズマジェットの分光学的温度の 径方向分布

Fig. 8. Radial profiles of the spectroscopic temperatures in the plasma jet.
では FR $1\left(l_{m}=6 \mathrm{~mm}\right)$ で 約 $6,800 \mathrm{~K}$, FR $3\left(l_{m}=18\right.$ $\mathrm{mm}) て ゙$ 約 5,500K, 100 Torr では FR $1\left(l_{m}=6 \mathrm{~mm}\right)$ で約 $6,900 \mathrm{~K}, \mathrm{FR} 3\left(l_{m}=18 \mathrm{~mm}\right) て ゙ 6,200 \mathrm{~K}$ となる。 従って, 両 $\mathrm{FR}$ を処理材料に用いた $\mathrm{Al}_{2} \mathrm{O}_{3}$ の沸点を 大幅に上回る高温を有することがわかる。また，特に 減圧下では FR 長を延ばした場合中心温度は約 $700 \mathrm{~K}$ しか低下せず, $\mathrm{Al}_{2} \mathrm{O}_{3}$ の沸点にほほ等しい約 $4,000 \mathrm{~K}$ の温度を有する半径は $2.5 \mathrm{~mm}$ から $3.5 \mathrm{~mm}$ に拡大す る。更に，材料送給口から温度測定点までの軸線上の 距離が FR 3 $\left(l_{m}=18 \mathrm{~mm}\right)$ は FR $1\left(l_{m}=6 \mathrm{~mm}\right)$ に比べ $12 \mathrm{~mm}$ も長いことを考慮すると, $\mathrm{Al}_{2} \mathrm{O}_{3}$ を蒸発させる ことが可能なプラズマ流の体積は增加したことにな る。つまり，FR 長を延ばすことによって FR内のプ ラズマ流の高温・高密度な領域が拡大されたことがわ かる。このためプラズマ流から材料粒子への熱伝達量 が増加し FR 内における粒子加熱が効果的に行われ, （1）項で示したように微粒子化が促進されたと考皇ら れる。

（3）プラズマ流中の粒子の加熱過程の計算

ここでは，上記の実験結果の定性的な検討のために も，単一粒子モデルを用いてプラズマ流中での注入粒 子の軌跡および温度履歷を計算し, 容器圧力が粒子加 熱に与える影響について検㰸した。

(i) 計算モデル 図 9 に計算モデルを示す。ア 一ク放電にガスを吹付け, 得られたプラズマジェット は，陽極下流に接続されたフィードリングを通過し圧 力容器内に噴出する。材料粒子はフィードリング入口 加 $3.5 \mathrm{~mm}$ 下流側の位置でプラズマ流に垂直に注入 され，プラズマ流の粘性により加速を受けると同時に 粒子とプラズマ流との温度差に応じた熱を得, 溶融, 蒸発を行う。更に，下流のプラズマジェット中では逆 に粒子は冷却され频固し微粒子が形成される。

注入された粒子の速度および温度は以下の運動方程 式，熱収支式(11)を解いて求めた。なお，計算に必要 なプラズマ流の温度と速度は FR 噴出後のプラスマジ エットにういては図 4, 図 5 に示す測定結果を用い た。また，FR内のプラズマ流の温度および速度につ いては，その二次元分布の計測が困難であるため，こ こでは朴ら ${ }^{(2)}$ が管内プラズマ流の計算に対して用い た手法を導入し，FR出口での温度および速度の剆定 值を境界条件として計算によって求めた值 ${ }^{(3)}$ を使用 した。その結果を図 10 , 図 11 に示す。比較のため に, 図 10 には同じ実験条件で得られた温度の実測值 をプロットしている。計算值は実験值と大差はないた め, FR ノズルの温度分布にこの計算値が十分使用 できることがわかる。 


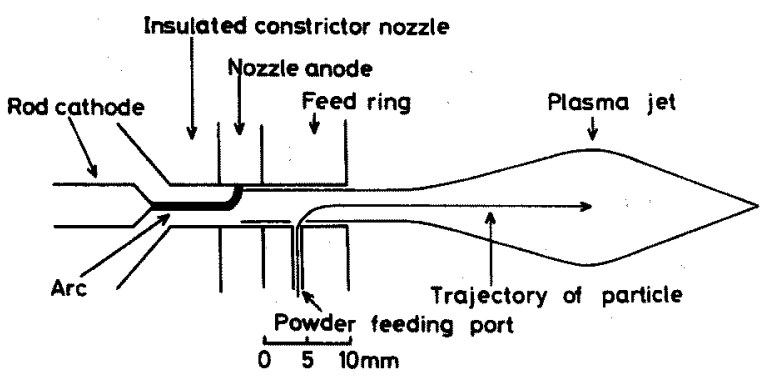

図 9 計算モデル

Fig. 9. Simulation.model.

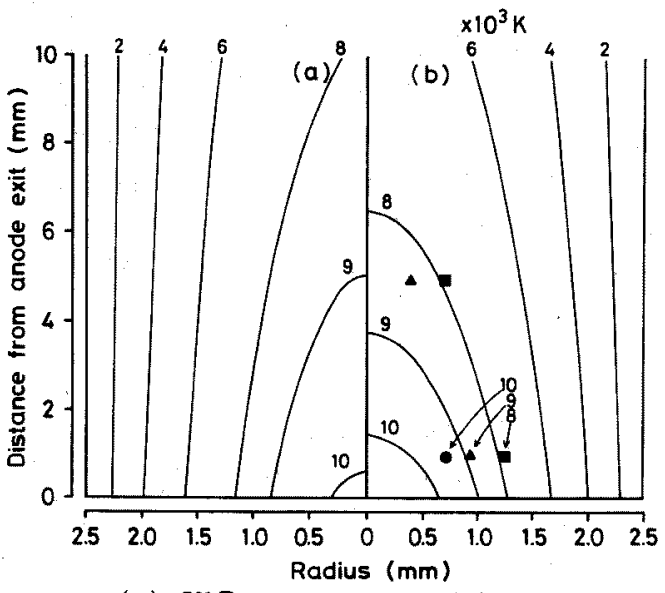

(a) 760 Torr

(b) $100 \mathrm{Torr}$

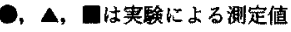

図 10 計算により求めた FR内のプラズマ流の 温度分布

Fig. 10. Calculated temperature fields of the plasma flow in the FR for different two pressures.

運動方程式

軸 $(z)$ 方向

$$
\frac{d V_{z}}{d t}=-\frac{3}{4} C_{D} \frac{\rho_{g}}{\rho_{p} D_{p}} V\left(V_{z}-V_{g}\right)+g \cdots \cdots(
$$

径 $(r)$ 方向

$$
\frac{d V_{r}}{d t}=-\frac{3}{4} C_{D} \frac{\rho_{g}}{\rho_{p} D_{p}} V V_{r}
$$

ただし，Vは平均速度で

$$
V=\left\{\left(V_{z}-V_{g}\right)^{2}+V_{r}^{2}\right\}^{\frac{1}{2}}
$$

\section{熱収支式}

(1) $T_{p}<T_{m}, \quad T_{m}<T_{p}<T_{v}$

$$
m_{p} C_{m p} \frac{d T_{p}}{d t}=h_{p} S_{p}\left(T_{s}-T_{p}\right)
$$

(2) $T_{p}=T_{m}$

電学論A，112 巻 4 号，平成 4 年

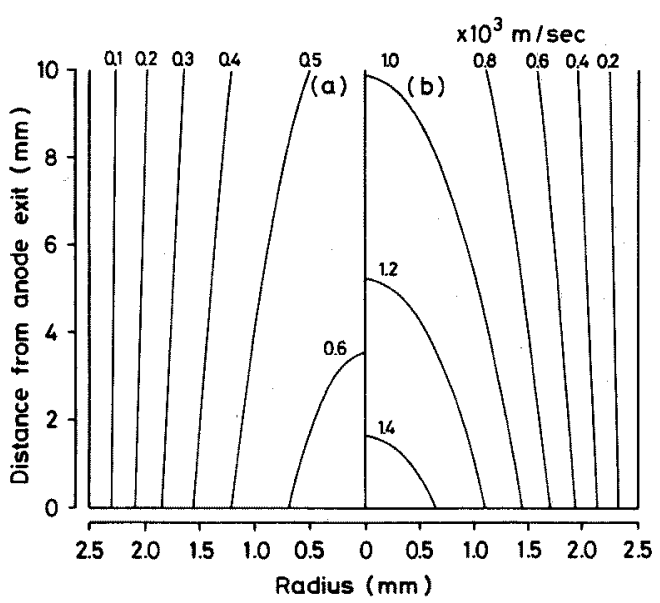
(a) 760 Torr
(b) 100 Torr

図 11 計算により求めた FR 内のプラズマ流の 速度分布

Fig. 11. Calculated velocity fields of the plasma flow in the FR for different two pressures.

$$
m_{p} L_{m} \frac{d T_{p}}{d t}=h_{p} S_{p}\left(T_{g}-T_{p}\right)
$$

(3) $\quad T_{p}=T_{v}$

$$
\frac{\rho_{p} \pi D_{p}{ }^{2}}{2 L_{v}} \frac{d T_{p}}{d t}=h_{p} S_{p}\left(T_{q}-T_{p}\right)
$$

ここで, $C_{D}$ : 抗力係数, $V_{\boldsymbol{g}}$ : プラズマ流の 速度, $\rho_{g}$ : プラズマ流の密度, $V_{z}$ : 粒子の 軸方向速度, $\rho_{p}$ : 粒子密度, $V_{r}$ : 粒子の径 方向速度, $m_{p}$ : 粒子の質量, $L_{m}$ : 融解熱, $C_{m p}$ : 粒子の比熱, $L_{v}$ : 蒸発熱, $h_{p}:$ ズマ流と粒子間の熱伝達係数, $T_{\theta}:$ プラズ マ流の温度, $S_{p}$ : 表面積, $T_{p}$ : 粒子温度, $t:$ 時間, $T_{m}:$ 粒子の融点, $g:$ 重力加速度, $T_{v}:$ 粒子の沸点, $D_{p}:$ 粒子径 
（1）式の右辺第 1 項は流体によって粒子に働く抗力 であり，第 2 項は重力加速度である。また（3） 〜 (5) 式の右辺はプラズマ流から粒子への対流および 熱伝達による熱輸送量を表す。

低密度気体中（低圧力下）を運動する粒子に対して は熱および運動量伝達に関して非連続奻果（クヌーセ ン効果）が無視できなくなる。本計算ではこの効果は 抗力係数および熱伝達係数を求める際に使用するヌッ セルト数に含まれる。抗力係数にはPhillips ${ }^{(14)}$ の值を 用い, ヌッセルト数はApeliad ${ }^{(15)}$ の方法によって求 めた。

粒子の温度は以下の(1)〜(4)の手順を繰返すことによ って求めた。

(1) (1)，（2)式を連立して解き，粒子のある時刻 での位置および速度を算出する。

(2) その粒子の位置におけるプラズマ流の温度を図 4 または図 10 から読取る。

(3)このフフフズマ流の温度を粒子の状態に応じて (3)〜 (5) 式のいずれかに代入し，粒子の温度を求め る。

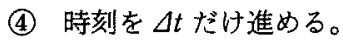

なお，ここでは粒子加熱が容器圧力によりどのよう な影響を受けるかに注目して容器圧力依存性の定性 的・半定量的な検討を目的としている。そこて，簡単

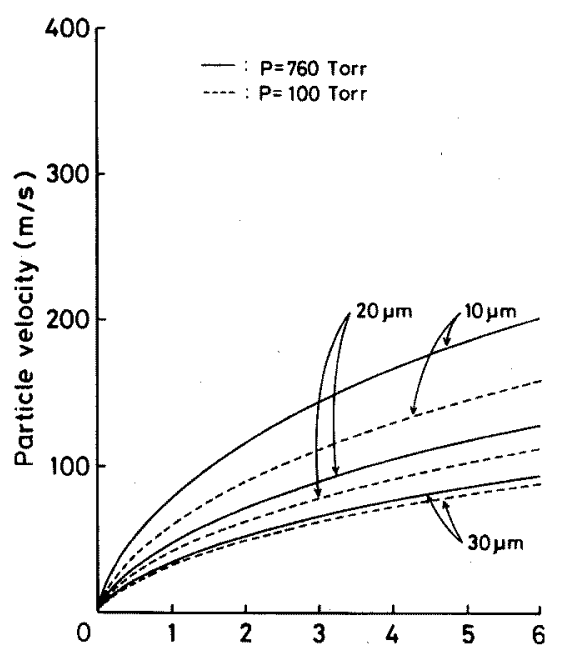

Distance from powder feeding port $(\mathrm{mm})$

図 12 面径の異なる材料粒子 $(10,20$, $30 \mu \mathrm{m})$ の FR 内の速度

Fig. 12. Calculated particle velocities for three different diameters $(10,20,30 \mu \mathrm{m})$ in the FR as a function of the distance from powder feeding port.
のためプラズマ流の半径方向速度は考慮せず，粒子は プラズマ流中の高温の領域を通過し，もっとも効果的 に加熱される場合について考えた。すなわち，粒子は 図 9 に示すように,FR 壁面からプラズマ流に対し垂 直に注入され，FR 出口でプラズマ流の中心軸上の位 置に到達し，更にFR噴出後はプラズマ流の中心軸上 を飛行するとした。粒子の初速度としては前述の軌跡 を描くよう選定し，また粒子の初期温度は $300 \mathrm{~K}$ と した。

（ii）計算結果むよび検討図 12 は容器圧力な らびに粒径の違いが FR 内での粒子の速度に及ぼす影 響を示している。注入された粒子はこの領域ではプラ ズマ流によって加速され，下流に進むほど高速度とな る。そして，この傾向は粒径が小さくなるほど強くな る。各粒子に対するプラズマ流中での滞留時間を求め ると粒径 10，20，30 $\mathrm{m}$ に対して大気圧下ては，73，

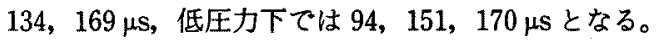
つまり FR内のプラズマ流中で滞留時間は粒径に大き く依存する。

注入された粒子の温度は図 13 にすように $P=$ 760 Torr では急激に加熱され直径の小さな粒子は融 点を経て沸点に達し，蒸発を始める。粒径が大きくな ると, 加熱される粒子の体積 (熱容量) が増すため, 粒径 $30 \mu \mathrm{m}$ の粒子は沸点に達しない。すなわち，粒 子の到達温度は粒径に依存する。一方低圧力下 $(P=$ 100 Torr) では，粒子は大気圧下に比べ加熱されにく くなり,FR出口（図の横軸が $6 \mathrm{~mm}$ の位置）におけ

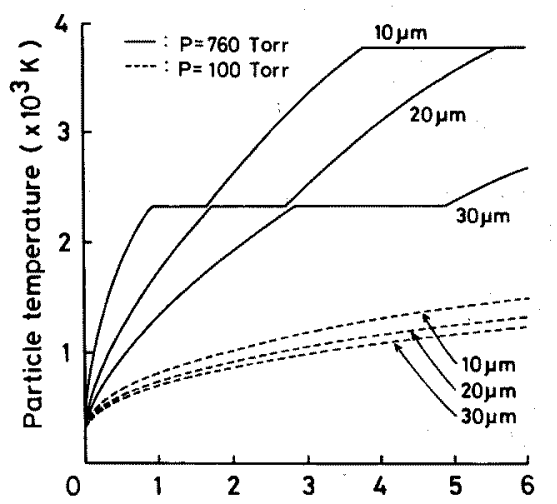

Distance from powder feeding port $(\mathrm{mm})$

図 13 直径の異なる材料粒子 $(10,20$, $30 \mu \mathrm{m})$ の FR 内の温度

Fig. 13. Calculated particle temperature for three different diameters $(10,20,30 \mu \mathrm{m})$ in the FR as a function of the distance from powder feeding port. 
る粒子温度は $1,200 \mathrm{~K}$ から $1,470 \mathrm{~K}$ の範囲であり，粒 径による温度差はほとんどない。プラズマ流中の滞留 時間はほぼ等しいにもかかわらず，このように粒子加 熱が容器圧力により大きく異なるのは，低圧力下では クヌーセン効果が強くなりプラズマ流から粒子への熱 伝達率が大きく低下するためであることがわかる。 FR 出口での熱伝達率を求めてみると, 例えば粒径 30 $\mu \mathrm{m}$ の場合低圧力下では大気圧下の約 $1 / 4$ にまで低下 する。

FR を通過した粒子は引続き圧力容器内に噴出した プラズマジェット中を飛行するが，このときの粒子の 温度, 速度の計算には FR 出口での先の計算結果を初 期值境界值（図 12，図 13 に示す $6 \mathrm{~mm}$ での值）とし て用いた。

図 14 は FR 噴出後の粒子の速度の変化を示す。粒 子はいずれの条件下でも更に加速を受けるが，粒子の 速度 $V_{\theta}$ がプラズマ流の速度を超えると徐々に減速さ れる。プラズマ流の速度が雲囲気圧力によって大きく 異なり，低圧力下ではプラズマ流の速度は大気圧下に 比べ著しく速いため注入粒子は FR 上り離れた位置で も高速て飛行する。

粒子温度の変化について図 15 に示すように, 粒子 はプラズマ流の温度 $T_{\theta}$ に等しくなる位置まで加熱さ

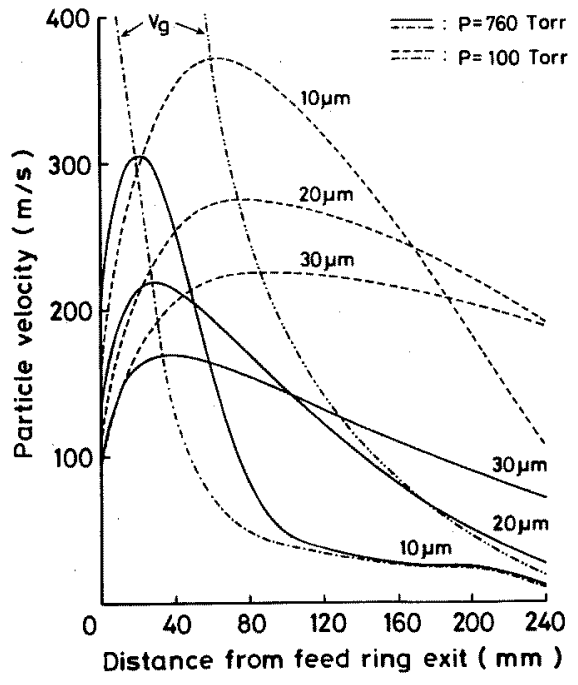

$$
V_{\diamond}: \text { プラスマジェットの速度 }
$$

図 14 直径の異なる材料粒子 $(10,20$, $30 \mu \mathrm{m})$ の FR 噴出後の速度

Fig. 14. Calculated particle velocities for three different diameters $(10,20,30 \mu \mathrm{m})$ in the plasma jet as a function of the distance from the FR exit.

要学論A，112 巻 4 号, 平成 4 年
れ，これを超えると冷却を受ける。その冷却効果もま た容器圧力により異なる。大気圧下では粒子は気相, 液相，固相という状態変化を行い，その温度履歷は粒 径により大きく異なる。一方, 減圧下ではプラズマ流 から材料粒子への熱伝達率が小さいために，粒子は融 点または融点に近い温度に達するのみで粒径による温 度履歴の違いはほとんどない。

上記の結果は粒子の加熱・冷却過程が容器圧力によ り大きな差を生じることを示している。すなわち，(1) 大気圧下ては粒子は急激に加熱され，その温度履歴は 粒径に大きく依存する，(2)低圧力下ではクヌーセン効 果が大きいため粒子は加熱されにくく，ほとんどの粒 子は融点または融点の近くまでしか加熱されず，温度 履歴の粒径による違いも小さい，更に，(3低圧力下て は粒子は FRより離れた位置においても高速で飛行す る,ということがわかった。

以上の結果を熱プラズマプロセスへの応用の観点か ら整理してみる。一般的なプロセス条件として，例え ばスプレイコーティングの場合は溶融状態にある粒子 を高速で基板に衝突させることが重要であり，微粒子 化を行う場合は粒子を沸点まで加熱し蒸発させること が必要である。これを計算結果と対応させて考えると プロセス条件として低圧力下の場合がスプレイコーテ イングに適しており，大気圧下の場合が微粒子化に適 しているといえる。本装置を用いた予備的な実駼結果 でも大気圧下では多数の微粒子が捕集され，低圧力下

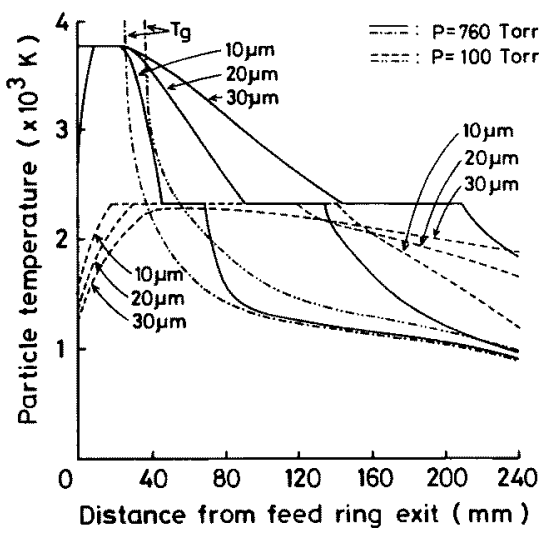

$T_{\theta}:$ プラスマジェットの温度

図 15 直径の異なる材料粒子（10，20， $30 \mu \mathrm{m})$ の FR 噴出後の温度

Fig. 15. Calculated particle temperature for three different diameters $(10,20,30 \mu \mathrm{m})$ in the plasma jet as a function of the dis tance from the FR exit. 
では溶融状態の粒子が多いことが確認されてお り (12), ここで得られた理論的予測を裏付ける結果と なっている。すなわち，概して低圧力下では粒子は加 熱されにくいことを示している。ところか゚, プロセス の高品質化・大容量化を目指すには微粒子化, スプレ イコーティングなどの処理を低圧力下で行う必要があ る。このためには, 低圧力下での熱伝達量の増加を図 らなければならない。この方法としては, (1)プラズマ 流の高温化, (2)滞留時間の延長, (3)熱伝達率の増加, が考えられる。(1)については発生器の絶縁収束部を延 長することで効果的にアーク入力を増加させることが 可能であることを確認している。(2)，(3)については FRの軸長をのばすことにより高温高密度のプラズマ 流の領域が拡大され, 熱伝達量の増加か゚可能であると 考えられる。〈3・2〉節 $(1)$ 項ならびに(2) 項に示し た実験結果はこれと定性的によく対応している。

\section{4.おわりに}

強制伸長型プラズマジェット発生器の前面に材料送 給用の FR を備えたプロセシング装置(9)を対象に, こ の装置の減圧下での高融点材料処理への応用可能性に ついて検討した。その結果を要約すると,

（1）本装置を用いて，高融点材料の超微粒子が多 数回収された。特に減圧下で FR 長を延ばすことによ り生成粒子数の増加が著しい。FR 1 (加熱を受ける 距離 $\left.l_{m}=6 \mathrm{~mm}\right)$ とFR $3\left(l_{m}=18 \mathrm{~mm}\right)$ を, 例えばノ ズル出口から $80 \mathrm{~mm}$ 下流の位置で比較すると $P=$ 760 Torr では FR $1\left(l_{m}=6 \mathrm{~mm}\right)$ の約 2 倍に, $P=100$ Torr では約 10 倍に増加する。

（2） $\mathrm{Al}_{2} \mathrm{O}_{3}$ (融点 $2,040^{\circ} \mathrm{C}$ ) だけでなく, 更に高融 点を有する $\mathrm{TiC}\left(\right.$ 融点 $\left.3,140^{\circ} \mathrm{C}\right), \operatorname{ZrC}\left(\right.$ 融点 $3,570^{\circ} \mathrm{C}$ ) についても超微粒子が多数回収された。

（3）プラズマジェット発生器の基礎特性に影響を 及ぼすことなく FR 長を延ばすことによりプラズマ流 の高温・高密度な領域を拡大することが可能である。 FR 長の最適值がいくらになるかは今後の検討課題で ある。

（4）単一粒子モデルによる解析ではあるが, 粉末 粒子のプラズマ流中での加熱過程を定性的には十分 に, 更に半定量的に検討した。プラズマジェットを減 圧下の熱プラズマプロセスに応用するためには, プラ ズマ流から材料粒子への熱伝達量を増加することが重 要であり，このための有効な指針が得られた。

以上より，本装置は FR 長によりプラズマ流から材 料粒子への熱伝達量の制御が可能であり, 大気圧下だ
けでなく減圧下においても高融点材料処理に十分有効 であることがわかった。

最後に, 御激励いたたくく本学名誉教授佐伯節夫先 生に感謝します。本研究に対して御討論いただいた大 崎 堅助教授, 内藤裕志助教授に感謝します。また, 本研究に御協力いただいた, 恩塚辰典, 酒井広隆, 渡 辺 真, 小田勝之助, 平原徹也の諸君に感謝します。 (平成 3 年 5 月 2 日受付, 同 3 年 10 月 28 日再受付)

\section{文 献}

(1) 板谷: 電学誌, 110,167 (平 2-3)

(2) 明石: 溶瀜塩, 28, 234 (昭 60)

（3）武田：金属学会会報, 24, 822 (昭 60)

(4) M. Yoshitaka, T. Yoshida \& K. Akashi : Rev. Sci. Instrum., 60, 248 (1988)

(5) S. Saeki, O. Fukumasa \& K. Osaki : Proc. 8th ISPC 1989 (1987)

（6）福政・恩塚・崎山・大崎・佐伯：第 6 回プラスマプロセシン グ研凟, p. 341 (平元)

（7）崎山・平原・福政・内藤・大崎：第8回プラスマプロセシン グ研资, p. 453 (平 3)

(8) 佐伯・内山：山口大学工学部研究報告, 27, 113 (昭 51)

(9) S. Saeki, O. Fukumasa, K. Matubara, K. Osaki \& I Yamada: Proc. 9th Symp. on ISIAT '85, p. 31 (1985)

(10) S. Saeki, O. Fukumasa, K. Osaki \& K. Matubara : Proc. 10th Symp. on ISIAT '86, p. 143 (1986)

(11) P. Fauchais, E. Boudrin \& J. F. Coudet: Topics in Current Chemistry 107, Plasma Chemistry IV, p. 93 (1983) Springer Verlag

（12）朴・本田・神沢：化学工学論, 13,613（昭 62）

（13）崎山・恩塚・渡辺・酒井・福政・内䐆 - 大崎・佐伯：山口大 学工学部研究報告, 40,243 (平元)

(14) W. F. Phillips: Phy. Fluid, 18, 1089 (1975)

(15) D. Apeliad, D. Wei \& M. Paliwal : Thin Solid Films, 118, 395 (1984)

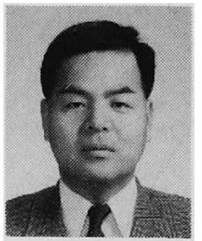

福 政修（正員）

昭和 21 年 1 月 8 日生。 48 年 3 月京都 大学大学院工学研究科電気工学専攻博士 課程修了。同年 4 月同大学助手。 57 年 山口大学工学部講師, 58 年同助教授, 63 年同教授, 現在に至る。工学博士。プラズマ理工学, 放電物理, プラズマ化学に関する研究に従事。物理学会, プラズマ・核融合学会, 電子情報通信学会, 照明学会会員。

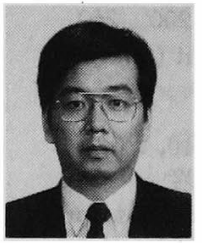
崎山智 司 (正員)

昭和 33 年 9 月 17 日生。 58 年 3 月山 口大学大学院工学研究科電気工学専攻修 士課程修了。同年 4 月同大学工学部助 手, 現在に至る。放電物理, プラスマ化 学に関する研究に従事。物理学会会員。 